\title{
СЕМАНТИЧЕСКИЕ СВОЙСТВА ГЛАГОЛОВ \\ В СИНТАКТИКЕ КИТАЙСКИХ ПРЕДЛОЖЕНИЙ
}

\section{Мазаева Софья Владимировна Оганезова Нина Левановна}

студенты

Научный руководитель: Каликова Анна Михайловна ФГБОУ ВО «Астраханский государственный университет»

\begin{abstract}
Аннотация: В работе рассматриваются семантические свойства китайских глаголов, которые влияют на выбор структуры китайских предложений. Авторы статьи проводят анализ имеющихся лексикограмматических классификаций китайских глаголов, выделяют их семантические свойства, задающие выбор синтаксической структуры китайских предложений.
\end{abstract}

Ключевые слова: глагольная семантика, китайский язык, синтаксическая структура, предложная конструкция.

\section{SEMANTIC PROPERTIES OF VERBS IN THE SYNTACTICS OF CHINESE SENTENCES}

\author{
Mazayeva Sofya Vladimirovna \\ Oganezova Nina Levanovna \\ Scientific adviser: Kalikova Anna Mikhailovna
}

\begin{abstract}
This work is devoted to the analysis of semantic properties of Chinese verbs that influences the choice of the Chinese sentence structure. The authors of the article analyze available lexical and grammatical classifications of the Chinese verbs, highlight their semantic properties which determine the choice of the syntactic Chinese structures.
\end{abstract}


Key words: verbal semantics, the Chinese language, syntactic structure, prepositional construction.

Лексическая номинация глагола на китайском языке передается словами 动 (рус. «двигаться, действовать») и 词 (рус. «слово»). Сочетаясь в одно слово, лексема 动词(рус. «глагол») имеет буквальный перевод - «двигательные слова». Такое номинативное сочетание сообщает морфологической категории глагола следующие значения: 1) движение, 2) действие, 3) изменение объекта. Данная статья посвящена рассмотрению основных семантических групп глаголов, которые выделяются грамматистами в современном китайском языке.

Согласно трактовке Тань Аошуан (2002), китайскими глаголами являются односложные или двусложные единицы, которые могут употребляться самостоятельно или в сочетании с другими знаменательными элементами предложения [1, с. 150]. Ввиду отсутствия морфологических словоформ и аналитических средств выражения грамматических признаков, китайские глаголы передают значения времени, аспекта, наклонения независимыми грамматическими показателями. В число таких показателей китайские грамматисты относят семантическое значение глагола или другие прагматические факторы, которые считаются нестандартными маркерами грамматических признаков для европейских языков [1, с. 148].

Одна из существующих глагольных классификаций исходит из синтаксических признаков китайского глагола. Данная классификация считается наиболее обширной, так как она основывается на свойствах глагольного управления в составе китайского предложения. Согласно грамматическим представлениям Ли Цзинь-си, китайские глаголы распределяются на следующие виды:

1. Переходные глаголы, принимающие после себя дополнение (外动词 wàidòngcí «глаголы внешнего действия»), распадаются на группы:

1) Глаголы действия (取 qǔ «брать», 吃 chī «есть», 作 zuò «делать»);

2) Глаголы восприятия (看 kàn «смотреть», 想 xiăng «думать», 知道 zhīdao «знать»);

3) Глаголы взаимодействия со вторым лицом (送 sòng «дарить», 夺 duó «отнимать», 问 wèn «спрашивать»); 
4) Глаголы побуждения (使 shǐ «заставлять», 请 qǐng «просить», 允许 yǔnxǔ «разрешать», 禁止 jìnzhй «запрещать»);

5) Глаголы номинации (认 rèn «считать, признавать», 叫 jiào «называть», 当 dāng «становиться»);

6) Глаголы изменения (改 găi «изменять», 化 huà «превращать», 分 fēn «разделять», 合 hé «соединять»);

7) Глаголы чувств и эмоций (爱 ài «любить», 佩服 pèifú «уважать, чтить», 笑 хіào «смеяться», 骂 mà «ругать» и т.п.);

8) Глаголы наличия (有 уǒu «иметь», 包括 bāokuo «включать») [2, с. 9].

Представленные группы содержат глаголы, которые могут принимать после себя дополнения, однако глаголы взаимодействия со вторым лицом и глаголы побуждения (группы 3 и 4) отличаются свойством принятия двух дополнений - прямого и косвенного (我要送他礼物 (рус. «Я хочу подарить ему подарок»), 老师问我们一些问题 (рус. «Учитель задал нам несколько вопросов»). Приведенные примеры отражают синтаксическую структуру следующего вида: Субъект + Глагол + Косвенное Дополнение + Прямое Дополнение.

2. Непереходные глаголы, не принимающие после себя дополнение (内动词 nèidòngcí «глаголы внутреннего действия»), имеют следующие подвиды:

1) Стандартные непереходные глаголы (来 lái «приходить», 走 zǒu «идти», 坐 zuò «сидеть», 睡 shuì «спать»);

2) Глаголы местоположения и перемещения (在 zài «находиться», 进 jìn «входить», 窑 zhú «высовываться, выглядывать») принимают после себя существительные со значением места;

3) Глаголы преобразования (变biàn «превращаться», 成chéng «становиться», 出现 chūxiàn «появляться») принимают после себя дополнительные члены;

3. Связочные глаголы (同动词 tóngdòngcí «глаголы связки») представлены синтаксическими элементами со значением связки 是 shì («быть, 
являться»), 当 dāng («становиться»), 为 wéi («быть»), а также прилагательными, выступающими в функции сказуемого.

4. Вспомогательные глаголы (助动词 zhùdòngcí) составляют глагольный вид, включающий:

1) модальные глаголы (可以 ké уг̌ «можно», 会 huì «мочь, уметь», 能 néng «Мочь»);

2) глаголы пассивного значения (被 bèi «подвергаться», 让 ràng «разрешать», 受 shòu «выносить», 挨 ái «терпеть»);

3) глаголы направления в их служебном значении (来 lái «приходить» и 去 qù «уходить») [2, с. 11].

Рассмотренная классификация совмещает два принципа грамматической дистрибуции китайских глаголов. Во-первых, перечисленные глаголы проанализированы с точки зрения их синтаксического взаимодействия в предложении. Во-вторых, обозначенные глаголы сгруппированы в соответствии с заключенным в них семантическим значением.

Вторая глагольная классификация была выведена А.А. Драгуновым в 1952 г. Её особенность заключается в лексико-морфологической отнесенности. А.А. Драгунов распределяет глаголы на основании лексического значения «наличия» или «отсутствия» действия [2, с. 12]. В результате, глаголы с лексическим значением «отсутствия действия» распределяются на группы:

1) глаголы мышления и чувств (明白 míngbai «понимать», 懂dǒng «знать», 喜欢хи̌huan «нравиться»;

2) модальные глаголы (应该yīnggāi «следует», 可能 kěnéng «мочь»);

3) полузнаменательные глаголы (像xiàng «походить на», 叫 jiào «называться», 姓xìng «зваться по фамилии»);

4) глаголы со значением «болеть» (疼téng «испытывать боль», 痛tòng («мучиться») [2, с. 12].

Глаголы с лексическим значением «наличия действия» распределяются по группам:

1) переходные глаголы; 
2) непереходные глаголы;

3) глаголы направления (出chū «выходить», 进jìn «входить», 到 dào «доходить», 去qù «уходить», 来lái «приходить»);

4) глаголы манипуляции над объектом (取qǔ «брать», 借jiè «одалживать», 还huán «возвращать»);

5) глаголы-предлоги (跟gēn «следовать за», 给gěi «давать», 起qǔ «начиная с») [2, с. 13].

Лексико-грамматическая классификация А. А. Драгунова проводит разграничение китайских глаголов на основе их морфологического изменения присоединением глагольных модификаторов, частиц и других морфологических показателей.

Таким образом, семантика китайских глаголов влияет на выбор синтаксической структуры китайского предложения, полнота которой в дальнейшем достигается за счет использования дополнения/ дополнений, глагольных модификаторов, грамматических показателей совершенного вида.

Говоря о семантико-грамматических свойствах китайских глаголов, следует обратить внимание на ряд особенностей. Прежде всего, в китайском языке глаголы обладают свойством редупликации. Такое грамматическое свойство позволяет им передавать значение непродолжительности выполняемого действия (请给我你的画报看看。 твой журнал почитать») [2, с. 19].

В. Ф. Щичко выделяет несколько функций редупликации китайских глаголов:

1. Удвоение глагола смягчает тон речи, его использование характерно для повелительных предложений, которым придается значение вежливости и тактичности (请等等。pyc. «Подождите немного»).

2. Удвоение глагола передает краткость, непринужденность совершенного действия. Выступая в данной функции, китайские глаголы переводятся на русский язык с помощью приставки по-, которая придаёт всему действию характер быстроты и лёгкости (这个问题要想一想。 $p y c$. «Над этим вопросом стоит подумать») [3, с. 67].

Другая грамматическая особенность китайских глаголов связана с образованием предложных конструкций. Предложная конструкция - это 
сочетание предлога (在zài, 给gěi) с последующим существительным [4, c. 12]. В китайских предложениях они выполняют функцию обстоятельства места или адресата действия, занимая позицию перед основным глаголом (см. Таблицу 1).

Таблица 1

\section{Порядок слов китайских предложений}

\begin{tabular}{|l|l|l|l|l|l|l|}
\hline \multirow{2}{*}{ Подлежащее } & \multicolumn{5}{|c|}{ Сказуемое } \\
\cline { 2 - 6 } & $\begin{array}{c}\text { наречие } \\
\text { времени }\end{array}$ & $\begin{array}{c}\text { обстоятельство } \\
\text { места }\end{array}$ & \multicolumn{1}{|c|}{ адресат } & глагол & дополнение & частица \\
\hline $\begin{array}{l}\text { 我朋友 } \\
\text { 他们 }\end{array}$ & 也 & 在食堂 & 跟同学们 & 吃 & 饺子。 & 吗 \\
她 & 都 & 给你 & 借 & 钱 \\
邮件。 & \\
\hline
\end{tabular}

Как показано в таблице 1, предложные конструкции нельзя ставить после глаголов. Исключение составляют:

1) глаголы 住zhù (рус. «жить»), 放 fàng «класть», 挂 guà «вешать», 坐 zuò «сидеть», 站 zhàn «стоять», 躺 táng «лежать», 掉 diào «падать», принимающие после себя предложные конструкции с указанием места совершенного действия (他住在美国。pyc. «Он живёт в США», 老师站在黑板那儿。pyc. «Преподаватель стоит у доски»).

2) глаголы借jiè (рус. «одалживать»), 还huán (pyc. «возвращать»), 教jiāo (рус. «обучать»), 问wèn (рус. «спрашивать»), 回答huídá (рус. «отвечать»), 告诉gàosu (рус. «рассказать»), 请qǐng (рус. «просить»), принимающие после себя косвенное дополнение без предлога (明天我想还你词典。pyc. «Завтра я хочу вернуть тебе словарь», 老师问我一些问题。 $p y c$. «Учитель задал нам несколько вопросов»).

В семантике первого ряда глагольных исключений обнаруживается единство передаваемого значения - «притяжение к земле». Семантика второго ряда глаголов отражает их коммуникативную сущность, которая может быть выражена значением «побуждения к действию».

Таким образом, рассмотренные в данной работе грамматические свойства китайских глаголов имеют непосредственное отношение к выражению их 
семантического значения, которое оказывает влияние на выбор синтаксической структуры в построении китайских предложений.

\section{Список литературы}

1. Тань Аошуан. Проблемы скрытой грамматики: Синтаксис, семантика и прагматика языка изолирующего строя языка изолирующего строя (на примере китайского языка). - Московский гос. ун-т; Ин-т стран Азии и Африки. - М.: Языки славянской культуры, 2002. - 896 с.

2. Карпека Д. А. Глагол и грамматические категории предикатов в современном китайском языке. - СПб.: Восточный экспресс, 2017. - 385 с.

3. Щичко В. Ф. Практическая грамматика современного китайского языка. - М.: Восточная книга, 2014. - 207 с.

4. Фролова М. Г. Китайский язык. Справочник по глаголам. - М.: Живой язык, 2010. - 224 с.

(C) С.В. Мазаева, Н.Л. Оганезова, 2021 